\title{
Effect of Alpha-Particle Irradiation on InGaP/GaAs/Ge Triple-Junction Solar Cells
}

\author{
Jing Xu ${ }^{1}$, Min Guo ${ }^{1}$, Ming Lu ${ }^{1} * \mathbb{D}^{\mathbb{D}}, \mathrm{Hu} \mathrm{He}{ }^{2}$, Guang Yang ${ }^{2}$ and Jianwen $\mathrm{Xu}^{2}$ \\ 1 Department of Physics, Yantai University, 30 Qingquan Road, Laishan District, Yantai 264005, China; \\ xj2012@mail.bnu.edu.cn (J.X.); 17853501729@163.com (M.G.) \\ 2 Shanghai Institute of Space Power-Sources, 2965 Dongchuan Road, Minhang District, Shanghai 200233, \\ China; hh28-121@163.com (H.H.); yg_shuihaozi@sina.com (G.Y.); 13671578748@163.com (J.X.) \\ * Correspondence: lum@ytu.edu.cn; Tel.: +86-0535-349-6035
}

Received: 6 May 2018; Accepted: 31 May 2018; Published: 4 June 2018

\begin{abstract}
InGaP/GaAs/Ge triple-junction solar cells were irradiated with $5.1 \mathrm{MeV}$ alpha particles with different fluences. The degradations of the optical and electrical properties of $\mathrm{InGaP} / \mathrm{GaAs} / \mathrm{Ge}$ solar cells were described in terms of the variation in the short-circuit current $\left(\mathrm{I}_{\mathrm{sc}}\right)$, the open-circuit voltage $\left(\mathrm{V}_{\mathrm{oc}}\right)$, the maximum power $\left(\mathrm{P}_{\max }\right)$, the spectral response $(\mathrm{SR})$, and the photoluminescence (PL) versus the $5.1 \mathrm{MeV}$ alpha-particle fluences. The degradation modeling of the $\mathrm{I}_{\mathrm{sc}}$ and $\mathrm{V}_{\mathrm{oc}}$ under $1 \mathrm{MeV}, 3 \mathrm{MeV}$, and $5.1 \mathrm{MeV}$ alpha-particle irradiation was performed by calculating the introduction rate of non-radiative recombination centers, and the minority-carrier capture cross section, and the results were in good agreement with experimental data. For comparison, the degradations of the $\mathrm{I}_{\mathrm{sc}}$ and $\mathrm{V}_{\mathrm{oc}}$ were presented under $1 \mathrm{MeV}$ and $3 \mathrm{MeV}$ proton irradiation.
\end{abstract}

Keywords: InGaP/GaAs/Ge solar cells; alpha-particle irradiation; current-voltage (I-V) characteristics; spectral response; photoluminescence; degradation

\section{Introduction}

The near-earth space radiation environment in which solar cells are located mainly consists of electrons and protons trapped in the earth's radiation belts. Specifically, galactic cosmic rays (GCRs) consist of $87 \%$ protons, $12 \%$ alpha particles, and $1 \%$ heavier ions, while solar particle events (SPEs) consist of $96.4 \%$ protons, $3.5 \%$ alpha particles, and $0.1 \%$ heavier ions [1]. However, this doesn't mean that the alpha particles and heavier ions in GCRs and SPEs can be ignored despite their small percentages. Protons and alpha particles, as well as heavier ions, degrade the optical and electrical properties of solar cells. In addition, when the particles in GCRs and SPEs travel through the earth's atmosphere, they interact with the electrons and the nuclei of atoms in the atmosphere, resulting in the production of secondary particles [2]. These secondary particles can also cause the degradation of solar cells. Therefore, it is necessary to study the response of solar cells under different types of particle irradiation in an effort to satisfy the requirements of high reliability and long life for spacecrafts.

For the past few years, the InGaP/GaAs/Ge triple-junction (3J) solar cells became the mainstream generation of space power in spacecraft due to its high conversion efficiency and radiation hardness [3-9]. However, the studies on the radiation response of InGaP/GaAs/Ge triple-junction solar cells were mostly concentrated on proton and electron irradiation [3-8], with few researches focusing on alpha-particle irradiation [9]. In Reference [3], the effects of $10 \mathrm{MeV}$ proton irradiation on InGaP/GaAs/Ge triple-junction solar cells were studied experimentally and theoretically. The results indicated that the damage of the GaAs subcell was the highest, while InGaP and Ge subcells exhibited slight signs of degradation with the same fluence. In Reference [5], the impact of $1 \mathrm{MeV}$ electron irradiation-induced non-radiative recombination centers on each subcell of the $\mathrm{InGaP} / \mathrm{InGaAs} / \mathrm{Ge}$ 
solar cell was analyzed in detail based on electroluminescence characteristics. The results indicated that the open-circuit voltages of the InGaP and Ge subcells showed only a little degradation, but a significant drop was observable for the InGaAs middle subcell. In fact, although the relative abundance of alpha particles is less than that of protons in SPEs and GCRs, the displacement damage of solar cells induced by alpha particles was more serious than that for protons at the same energy because the non-ionizing energy loss (NIEL) of alpha particles is about 10 times that of protons [10]. Additionally, alpha-particle energy can be as high as $10^{14} \mathrm{MeV}$ and $10^{3} \mathrm{MeV}$ in GCRs and SPEs, respectively [1]. These high-energy alpha particles can travel through the cover glass in the front surface of the solar cells, and fall on the active regions of the cells, causing the degradation of their optical and electrical properties.

In our previous work, we studied the radiation effects on InGaP/GaAs/Ge solar cells under $0.32-3 \mathrm{MeV}$ proton irradiation and under $1-11.5 \mathrm{MeV}$ electron irradiation $[7,8]$. On this basis, we firstly analyzed the degradation of the optical and electrical properties of $\mathrm{InGaP} / \mathrm{GaAs} / \mathrm{Ge}$ solar cells under $5.1 \mathrm{MeV}$ alpha-particle irradiation based on current-voltage (I-V) characteristics, spectral response (SR), and photoluminescence (PL) measurements. We then simulated the degradation of the short-circuit current $\left(\mathrm{I}_{\mathrm{sc}}\right)$ and the open-circuit voltage $\left(\mathrm{V}_{\mathrm{oc}}\right)$ under $1 \mathrm{MeV}, 3 \mathrm{MeV}$, and $5.1 \mathrm{MeV}$ alpha-particle irradiation by calculating the introduction rate of non-radiative recombination centers, and the minority-carrier capture cross section. Finally, we compared the degradation behaviors of $\mathrm{I}_{\mathrm{sc}}$ and $\mathrm{V}_{\mathrm{oc}}$ under $1 \mathrm{MeV}$ and $3 \mathrm{MeV}$ alpha-particle and proton irradiation.

\section{Materials and Methods}

The InGaP/GaAs/Ge 3J solar cells were fabricated on Ge substrates by metalorganic chemical vapor deposition. The solar cells consisted of InGaP top cells, GaAs middle cells, and Ge bottom cells. The thicknesses of the InGaP, GaAs, and Ge subcells were about $1.2 \mu \mathrm{m}, 3 \mu \mathrm{m}$, and $1 \mu \mathrm{m}$, respectively. Each subcell was connected by a tunnel junction. The detailed structures of the solar cells are shown in Reference [11] (p. 746).

The InGaP/GaAs/Ge 3J solar cells were irradiated by alpha particles liberated from a ${ }^{239} \mathrm{Pu}$ surface source. Five ${ }^{239} \mathrm{Pu}$ alpha sources were chosen for the irradiation experiment, and all sources were disc-shaped with a diameter $(d)$ of $2.5 \mathrm{~cm}$. The total activity $(A)$ of the ${ }^{239} \mathrm{Pu}$ source, as well as the irradiation time $(t)$, is listed in Table 1 . The fluences $(\varphi)$ were expressed as $\varphi=4 A t / \pi d^{2}$, and its values are listed in Table 1. During the decay of ${ }^{239} \mathrm{Pu}$ to ${ }^{235} \mathrm{U}, 70.8 \%$ of the alpha particles were emitted with an energy which peaked sharply at $5.157 \mathrm{MeV}$, while $17.1 \%$ had an energy of $5.144 \mathrm{MeV}$, and $11.9 \%$ had an energy of $5.105 \mathrm{MeV}$ [12]. The alpha particles of these three energies $(5.157 \mathrm{MeV}$, $5.144 \mathrm{MeV}$, and $5.105 \mathrm{MeV}$ ) accounted for $99.8 \%$ of all the alpha particles liberated from the ${ }^{239} \mathrm{Pu}$ source, and their values were very close. Therefore, the alpha particles liberated from the ${ }^{239} \mathrm{Pu}$ source were approximately considered as $5.1 \mathrm{MeV}$ monoenergetic particles in this paper. The experiment was performed in the air. During the experiment, the solar cells with no cover glass were attached tightly to the surface of the ${ }^{239} \mathrm{Pu}$ sources. It was assumed that the thickness of the air layer between the ${ }^{239} \mathrm{Pu}$ source and the solar cell was negligibly small. Therefore, we considered that there was almost no alpha-particle energy loss in the area between the Pu source and the solar cell.

Table 1. The values of irradiation time $(t)$, fluence $(\varphi)$, and total activity $(A)$.

\begin{tabular}{cccccc}
\hline Parameters & Source 1 & Source 2 & Source 3 & Source 4 & Source 5 \\
\hline$A(\mathrm{~Bq})$ & $1.20 \times 10^{2}$ & $4.23 \times 10^{2}$ & $3.47 \times 10^{3}$ & $1.03 \times 10^{3}$ & $3.20 \times 10^{3}$ \\
$t(\mathrm{~h})$ & 227 & 247 & 218 & 1360 & 2130 \\
$\varphi\left(\mathrm{cm}^{-2}\right)$ & $2.0 \times 10^{7}$ & $7.6 \times 10^{7}$ & $5.6 \times 10^{8}$ & $1.0 \times 10^{9}$ & $5.0 \times 10^{9}$ \\
\hline
\end{tabular}

The I-V characteristics of the InGaP/GaAs/Ge 3J solar cells before and after alpha-particle irradiation were measured under Air Mass zero (AM0) using a solar simulator with an illumination of $136.7 \mathrm{~mW} \cdot \mathrm{cm}^{-2}$. The $\mathrm{I}_{\mathrm{sc}}, \mathrm{V}_{\mathrm{oc}}$, and maximum power $\left(\mathrm{P}_{\max }\right)$ were extracted from the $\mathrm{I}-\mathrm{V}$ measurements. 
The SR of the InGaP top cells and GaAs middle cells were measured before and after alpha-particle irradiation in various bias-light conditions. The PL spectra of the InGaP top cells and GaAs middle cells were measured before and after alpha-particle irradiation by a $532 \mathrm{~nm}$ and a $730 \mathrm{~nm}$ laser, respectively.

\section{Results and Discussion}

\subsection{The Distribution of the Displacement Damage in Solar Cells}

For the displacement-damage estimation, the non-ionizing energy loss (NIEL) gave the portion of energy lost due to displacement damage. The NIEL for the $5.1 \mathrm{MeV}$ alpha particles in the InGaP/GaAs/Ge 3J solar cells was simulated by the Stopping and Range of Ions in Matter (SRIM) [13], and is shown in Figure 1. The displacement threshold energies used in the simulation were $10 \mathrm{eV}$ for both $\mathrm{Ga}$ and As, $6.7 \mathrm{eV}$ for In, $8.7 \mathrm{eV}$ for P, and $27 \mathrm{eV}$ for Ge [11]. In Figure 1, the Bragg damage peak of the $5.1 \mathrm{MeV}$ alpha particles occurred at the end of the track at a depth of $11 \mu \mathrm{m}$, and was far away from the major active region of the three subcells. Thus, it was assumed that the distribution of displacement damage in the three subcells was uniform, and that the NIEL $\approx 0.3 \mathrm{MeV} \cdot \mathrm{cm}^{2} \cdot \mathrm{g}^{-1}$ for the 5.1 MeV alpha particles.

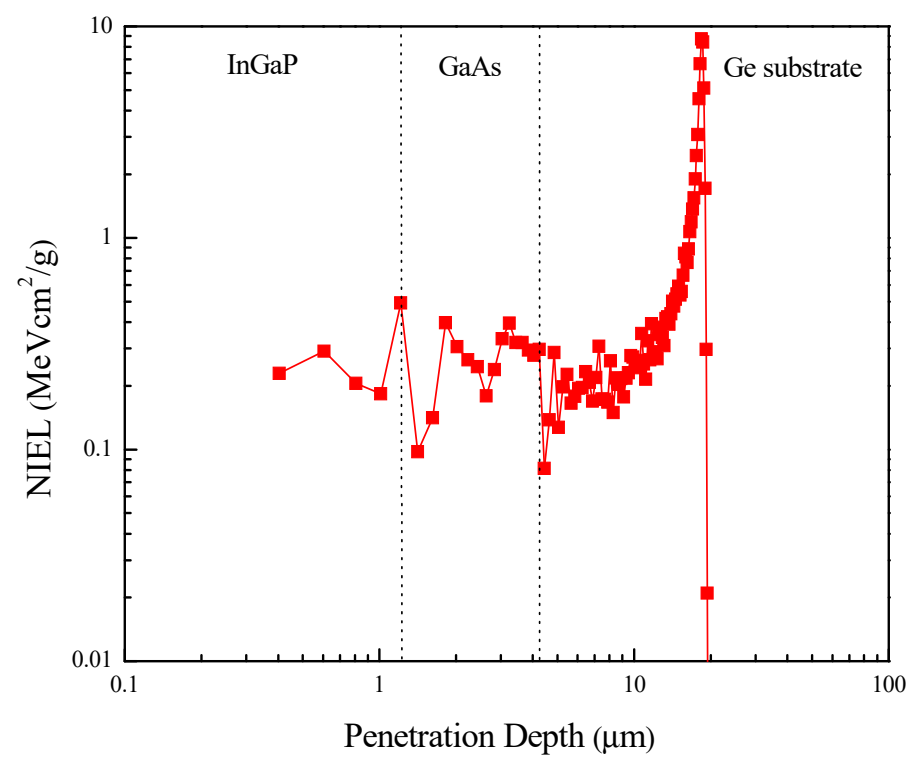

Figure 1. Non-ionizing energy loss (NIEL) as a function of $5.1 \mathrm{MeV}$ alpha-particle penetration depth in the InGaP/GaAs/Ge solar cells.

\subsection{I-V Characteristics before and after Alpha-Particle Irradiation}

The absorbed dose, which is a product of energy deposited by ionizing radiation in a certain mass of material, can be calculated by multiplying alpha-particle fluence and NIEL. Figure 2 shows the degradation trends of $\mathrm{I}_{\mathrm{sc}}, \mathrm{V}_{\mathrm{oc}}$, and $\mathrm{P}_{\max }$ in $\mathrm{InGaP} / \mathrm{GaAs} / \mathrm{Ge}$ solar cells as a function of the absorbed dose.

The degradation rates of the $\mathrm{I}_{\mathrm{sc}}, \mathrm{V}_{\mathrm{oc}}$, and $\mathrm{P}_{\max }$ increased with an increase in absorbed dose. The primary reason for the degradation of $\mathrm{I}_{\mathrm{Sc}}, \mathrm{V}_{\mathrm{oc}}$, and $\mathrm{P}_{\max }$ is the reduction of the minority-carrier lifetime due to alpha-particle radiation-induced recombination centers in solar cells. As seen in Figure 2, $\mathrm{P}_{\max }$ degradation was the most remarkable, as $\mathrm{P}_{\max }$ is proportional to the product of the current and the voltage. The $I_{S C}$ degraded less than the $V_{o c}$, because $V_{o c}$ degradation was contributed to by the sum of all three subcells, while $\mathrm{I}_{\mathrm{sc}}$ degradation was only contributed to by one of the three subcells. 


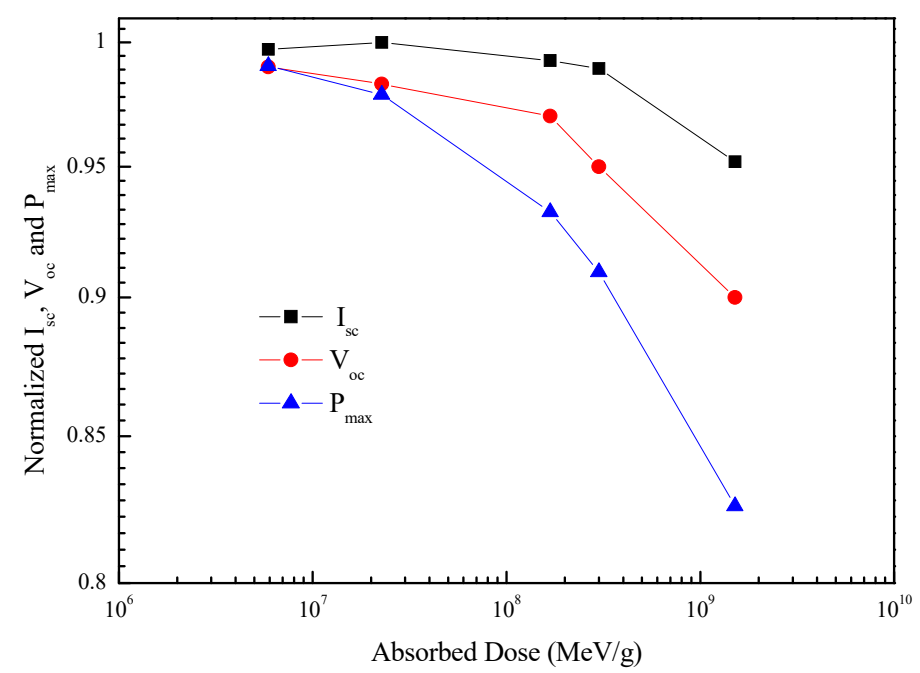

Figure 2. Normalized short-circuit current $\left(\mathrm{I}_{\mathrm{sc}}\right)$, open-circuit voltage $\left(\mathrm{V}_{\mathrm{oc}}\right)$, and the maximum power $\left(\mathrm{P}_{\max }\right)$ in the InGaP/GaAs/Ge triple-junction (3J) solar cells as a function of the absorbed dose.

\subsection{The SR before and after Alpha-Particle Irradiation}

Figure 3 shows the changes in SR of the InGaP top cells and GaAs middle cells before and after $5.1 \mathrm{MeV}$ alpha-particle irradiation with fluences of $1 \times 10^{9} \mathrm{~cm}^{-2}$ and $5 \times 10^{9} \mathrm{~cm}^{-2}$. The SR of the Ge bottom cells was not plotted in Figure 3 because the Ge subcells had a big-current and a small-voltage contribution to the InGaP/GaAs/Ge 3J solar cells [7]. In Figure 3, it can be noted that the SR dropped at wavelengths ranging from $650 \mathrm{~nm}$ to $900 \mathrm{~nm}$ for the GaAs middle cells after alpha-particle irradiation. However, the SR hardly decreased at wavelengths ranging from $350 \mathrm{~nm}$ to $650 \mathrm{~nm}$ for the InGaP top cells. This was mainly because there was lower migration energy of In $(0.26 \mathrm{eV})$ and P $(1.2 \mathrm{eV})$ in InGaP when compared with that of $\mathrm{Ga}(1.79 \mathrm{eV})$ and $\mathrm{As}(1.48 \mathrm{eV})$ in $\mathrm{GaAs}$ [14]. This meant that the GaAs middle cells were less radiation-resistant than the InGaP top cells. For InGaP/GaAs/Ge 3J solar cells, the photovoltage is the sum of the voltage for all three subcells, while the photocurrent is limited to the smallest value for any of the three subcells [15]. As a result, the degradation of the InGaP/GaAs/Ge solar cells was primarily controlled by the most radiation-sensitive subcell. Therefore, according to the SR measurements in Figure 3, the degradation of the InGaP/GaAs/Ge 3J solar cells was primarily controlled by the GaAs middle cells after alpha-particle irradiation.

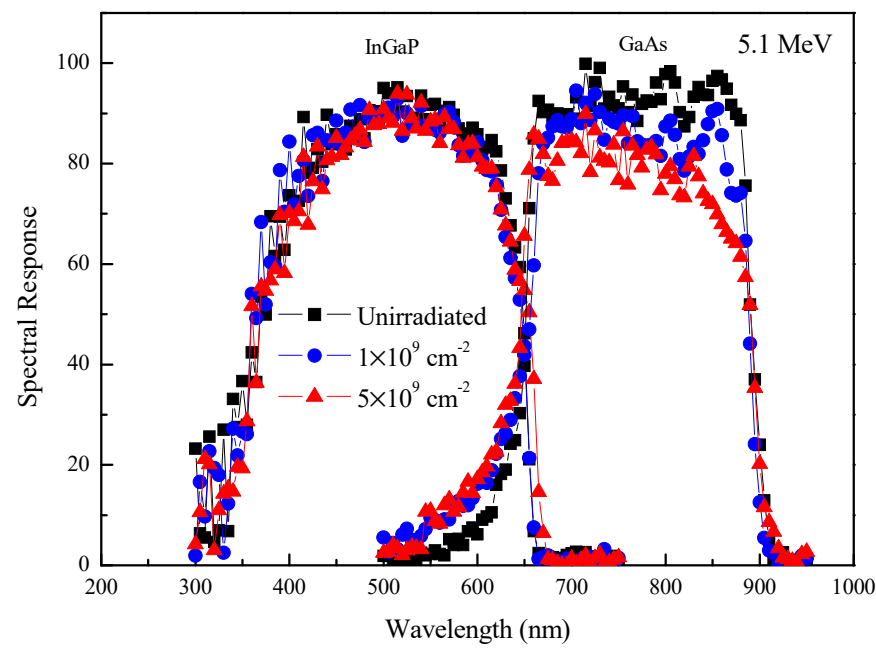

Figure 3. Spectral response of the InGaP top cells and GaAs middle cells before and after $5.1 \mathrm{MeV}$ alpha-particle irradiation with various fluences. 


\subsection{The PL Spectra before and after Alpha-Particle Irradiation}

Figure 4 shows the changes in PL spectra of the InGaP top cells and GaAs middle cells at room temperature before and after $5.1 \mathrm{MeV}$ alpha-particle irradiation with various fluences. As in Section 3.3, the PL spectra of the Ge bottom cells were not plotted in Figure 4. The PL intensity of the InGaP top cells and GaAs middle cells decreased with an increase in alpha-particle fluence, but the PL degradation of the GaAs middle cells was more than that of the InGaP top cells. This further corroborated that the GaAs middle cells were less radiation-resistant than the InGaP top cells.

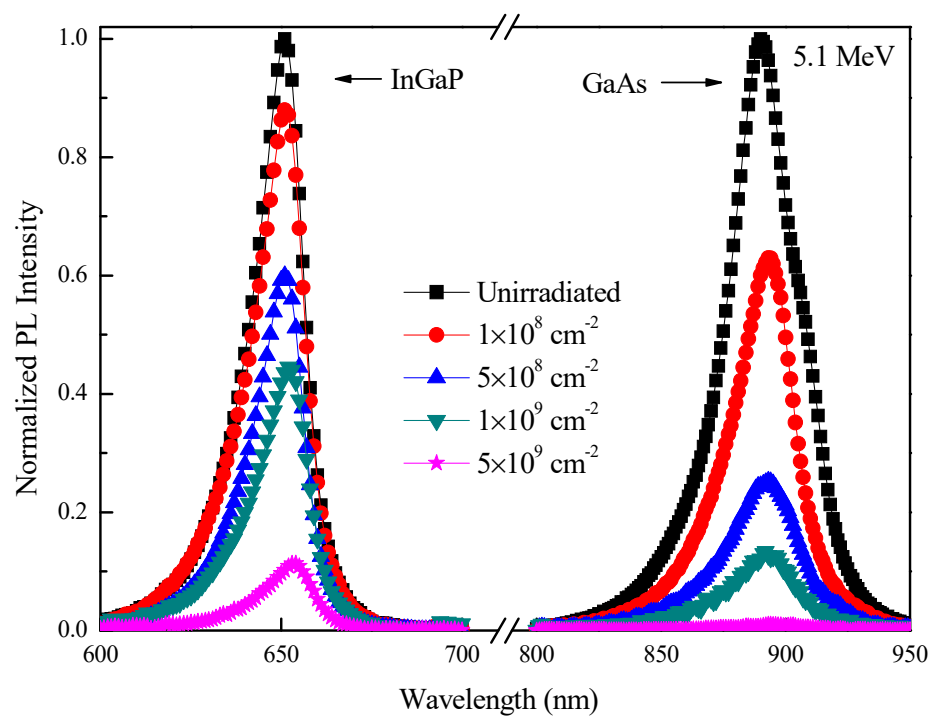

Figure 4. Photoluminescence (PL) spectra at room temperature of the InGaP top cells and GaAs middle cells before and after alpha-particle irradiation with various fluences.

Figure 5 shows the changes in normalized PL peak intensity of the InGaP top cells and GaAs middle cells after alpha-particle irradiation with an absorbed dose ranging from $3 \times 10^{7} \mathrm{MeV} / \mathrm{g}$ to $1.5 \times 10^{9} \mathrm{MeV} / \mathrm{g}$. The relationship between PL peak intensity $(\eta)$ and the absorbed dose $(D)$ can be expressed as [16]

$$
\eta=\left(1+\frac{\alpha}{\text { NIEL }} D\right)^{-1}
$$

where $\alpha=k \sigma v / B N$, and $k$ is the introduction rate of the non-radiative recombination centers, $\sigma$ is the minority-carrier capture cross section, $v$ is the thermal velocity of the carriers, $B$ is the radiative recombination probability, and $N$ is the doping concentration. The values of $v, B$, and $N$ are listed in Table 2.

As shown in Figure 5, the fitting curve obtained by Relationship (1) agreed with experimental data. The fitting parameters $(\alpha)$ are listed in Table 2. The values of $k \sigma$ were calculated, and are also listed in Table 2. Next, the values of $k \sigma$ for the GaAs middle cell were used for modeling the degradation of the InGaP/GaAs/Ge 3J solar cells, which was primarily controlled by the GaAs middle cell after alpha-particle irradiation.

Table 2. Values of $\alpha, v, B, N$, and $k \sigma$ for $5.1 \mathrm{MeV}$ alpha-particle irradiation in the InGaP and GaAs subcells.

\begin{tabular}{cccccc}
\hline Cells & $\boldsymbol{\alpha}\left(\mathrm{cm}^{2}\right)$ & $\boldsymbol{v}(\mathrm{cm} / \mathbf{s})$ & $\boldsymbol{B}\left(\mathrm{cm}^{\mathbf{3}} \cdot \mathbf{s}^{-\mathbf{1}}\right)$ & $\boldsymbol{N}\left(\mathrm{cm}^{-3}\right)$ & $\boldsymbol{k} \boldsymbol{\sigma}(\mathrm{cm})$ \\
\hline InGaP & $1.3 \times 10^{-9}$ & $3.5 \times 10^{7}$ & $2 \times 10^{-10}$ & $1 \times 10^{16}$ & $7.4 \times 10^{-11}$ \\
GaAs & $6.6 \times 10^{-9}$ & $5 \times 10^{7}$ & $1.5 \times 10^{-10}$ & $6 \times 10^{15}$ & $1.2 \times 10^{-10}$ \\
\hline
\end{tabular}




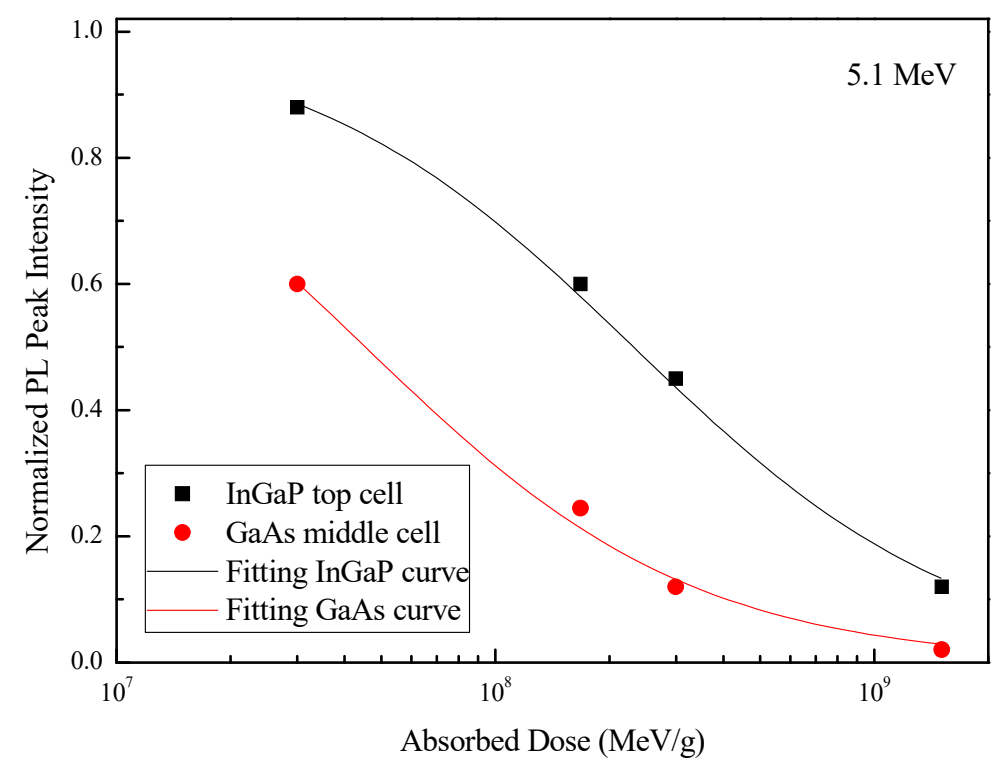

Figure 5. Normalized PL peak intensity of the InGaP top cells and GaAs middle cells as a function of the absorbed dose.

\subsection{Degradation Modeling of the Solar Cells}

Degradation modeling of the InGaP/GaAs/Ge 3J solar cells under alpha-particle irradiation with various energies and fluences was performed using a theoretical method $[17,18]$. This approach was introduced in detail in our previous work [18]. In this method, we considered that the main reason for the degradation of the solar cells was the non-radiative recombination centers induced by alpha-particle irradiation in the active regions of the cells. Therefore, according to the $k \sigma$ value for the GaAs cells in Table 2, the degradation curves for $\mathrm{I}_{\mathrm{sc}}$ and $\mathrm{V}_{\mathrm{oc}}$ as a function of the fluence under $5.1 \mathrm{MeV}$ alpha-particle irradiation were obtained, and are shown in Figures 6 and 7, respectively. The degradation curves showed good agreement with experimental data. For modeling the degradation of solar cells under various alpha-particle energies, the $k \sigma$ values can be calculated by the following relationship [17]:

$$
k \sigma(E)=\beta \operatorname{NIEL}(E),
$$

where $E$ is the incident alpha-particle energy, $\beta$ is a constant, and NIEL is the non-ionizing energy loss. For $5.1 \mathrm{MeV}$ alpha particles in the GaAs material, NIEL $=0.3 \mathrm{MeV} \cdot \mathrm{cm}^{2} \cdot \mathrm{g}^{-1}[19]$, and $k \sigma=1.2 \times 10^{-10} \mathrm{~cm}$ (see Table 2). Therefore, according to Relationship (2), $\beta=4 \times 10^{-10} \mathrm{~g} \cdot \mathrm{MeV}^{-1} \cdot \mathrm{cm}^{-3}$. As an example, $1 \mathrm{MeV}$ and $3 \mathrm{MeV}$ alpha particles were selected, and their NIEL is listed in Table 3. The values of $k \sigma$ for $1 \mathrm{MeV}$ and $3 \mathrm{MeV}$ alpha particles were calculated using Relationship (2), and are also listed in Table 3.

Table 3. Values of non-ionizing energy loss (NIEL) and $k \sigma$ for $1 \mathrm{MeV}$ and $3 \mathrm{MeV}$ alpha particles in the GaAs material.

\begin{tabular}{ccc}
\hline Alpha-Particle Energy $(\mathrm{MeV})$ & NIEL $\left(\mathrm{MeV} \cdot \mathrm{cm}^{\mathbf{2}} \cdot \mathrm{g}^{-\mathbf{1}}\right)$ & $\boldsymbol{k} \boldsymbol{\sigma}(\mathrm{cm})$ \\
\hline 1 & $1.5^{1}$ & $6 \times 10^{-10}$ \\
3 & $0.5^{1}$ & $2 \times 10^{-10}$ \\
\hline
\end{tabular}

${ }^{1}$ Reference [19]. 


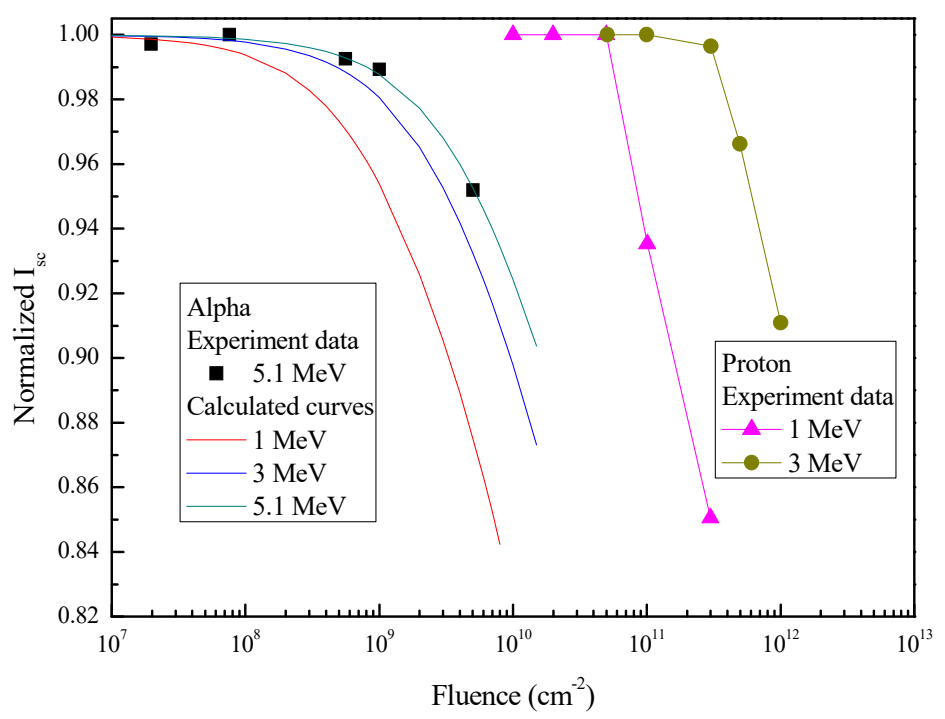

Figure 6. Normalized $\mathrm{I}_{\mathrm{sc}}$ of the InGaP/GaAs/Ge solar cells as a function of the fluence for various alpha-particle and proton energies.

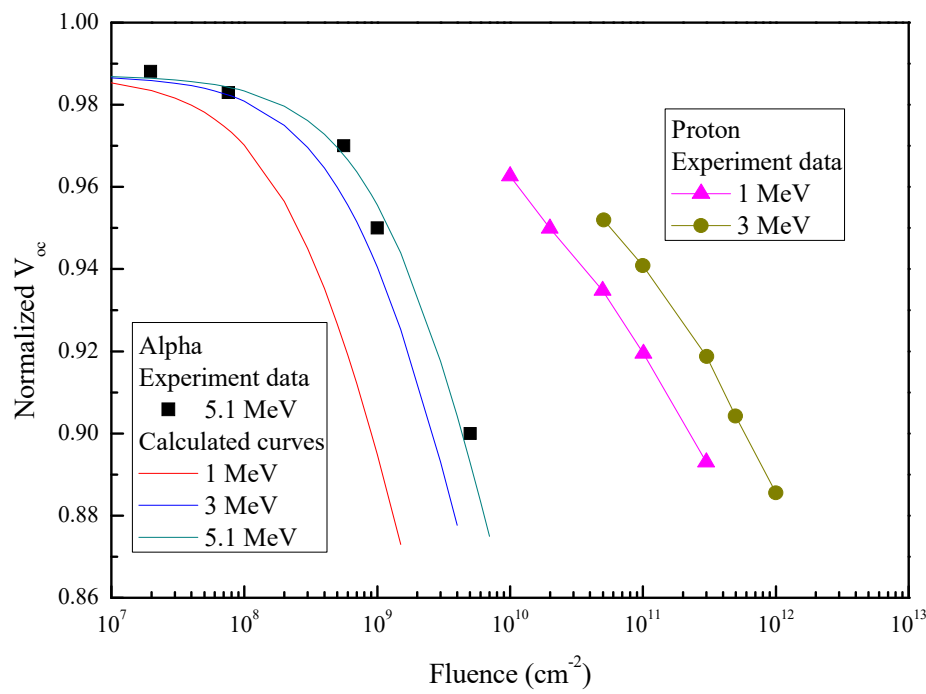

Figure 7. Normalized $\mathrm{V}_{\mathrm{oc}}$ of the InGaP/GaAs/Ge solar cells as a function of the fluence for various alpha-particle and proton energies.

According to the $k \sigma$ values in Table 3, the degradations of $\mathrm{I}_{\mathrm{sc}}$ and $\mathrm{V}_{\mathrm{oc}}$ for $1 \mathrm{MeV}$ and $3 \mathrm{MeV}$ alpha-particle irradiation were predicted, and are shown in Figures 6 and 7, respectively. Meanwhile, the degradation data of $\mathrm{I}_{\mathrm{sc}}$ and $\mathrm{V}_{\mathrm{oc}}$ for $1 \mathrm{MeV}$ and $3 \mathrm{MeV}$ proton irradiation are also shown in Figures 6 and 7, respectively. As seen in both figures, the fluence of alpha-particle irradiation was about two orders of magnitude lower than that of proton irradiation for the same energy, when the degradation was identical. This was mainly because the introduction rate of defects for alpha particles is much larger than that for protons [20]. This meant that, although the relative abundance of alpha particles is lower than that of protons in the space environment, alpha particles cause a more serious degradation of space solar cells than that due to protons.

\section{Conclusions}

The effects of $5.1 \mathrm{MeV}$ alpha-particle irradiation on InGaP/GaAs/Ge 3J solar cells were studied in detail using I-V characteristics, and measurements of SR and PL. Alpha particles had influence on the 
GaAs subcell, while having less influence on the InGaP subcell. The products of $k \sigma$ for $1 \mathrm{MeV}, 3 \mathrm{MeV}$, and $5.1 \mathrm{MeV}$ alpha particles were calculated by means of PL spectra and NIEL. The degradations of $\mathrm{I}_{\mathrm{sc}}$ and $\mathrm{V}_{\mathrm{oc}}$ under $1 \mathrm{MeV}, 3 \mathrm{MeV}$, and $5.1 \mathrm{MeV}$ alpha-particle irradiation were simulated, and the results were in good agreement with experimental data. In summary, alpha particles in the space environment cannot be ignored, as they can cause a more serious degradation of space solar cells than that due to protons.

Author Contributions: M.L. formulated the research ideas, and supervised the experiments; J.X. performed and interpreted the alpha-particle irradiation and PL experiments; M.G. wrote the programs for modeling the degradation of the solar cell; H.H., G.Y. and J.W.X. provided the high-quality sample of solar cells, and performed the measurements of I-V characteristics and spectral response. J.X. wrote the manuscript, and the other authors revised it.

Funding: This research was funded by Natural Science Foundation of Shandong Province grant number [ZR2016AQ02] and National Natural Science Foundation of China grant number [11605150, 11547151].

Acknowledgments: The authors would like to thank Professor Rong Wang of Beijing Normal University for the fruitful discussions, and his help in the PL measurements.

Conflicts of Interest: The authors declare no conflict of interest.

\section{References}

1. Bourdarie, S.; Xapsos, M.; Member, S. The near-earth space radiation environment. IEEE Trans. Nucl. Sci. 2008, 55, 1810-1832. [CrossRef]

2. Paschalis, P.; Mavromichalaki, H.; Dorman, L.I.; Plainaki, C.; Tsirigkas, D. Geant4 software application for the simulation of cosmic ray showers in the Earth's atmosphere. New Astron. 2014, 33, 26-37. [CrossRef]

3. Ochoa, M.; Yaccuzzi, E.; Espinet-Gonzalez, P.; Barrera, M.; Barrigon, E.; Ibarra, M.L.; Contreras, Y.; Garcia, J.; Lopez, E.; Alurralde, M.; et al. $10 \mathrm{MeV}$ proton irradiation effects on GaInP/GaAs/Ge concentrator solar cells and their component subcells. Sol. Energy Mater. Sol. Cells 2017, 159, 576-582. [CrossRef]

4. Tex, D.M.; Ihara, T.; Nakamura, T.; Imaizumi, M.; Ohshima, T.; Kanemitsu, Y. Evaluation of subcell power conversion efficiencies of radiation-damaged triple-junction solar cells using photoluminescence decays. Prog. Photovolt. 2017, 12, 1005-1014. [CrossRef]

5. Hoheisel, R.; Dimroth, F.; Bett, A.W.; Messenger, S.R.; Jenkins, P.P.; Walters, R.J. Electroluminescence analysis of irradiated GaInP/GaInAs/Ge space solar cells. Sol. Energy Mater. Sol. Cells 2013, 108, 235-240. [CrossRef]

6. Meng, J.R.; Feng, J.; Sun, Q.; Pan, Z.Q.; Liu, T.Y. Degradation model of the orbiting current for GaInP/GaAs/Ge triple-junction solar cells used on satellite. Sol. Energy 2015, 122, 464-471. [CrossRef]

7. Lu, M.; Wang, R.; Liu, Y.H.; Hu, W.T.; Feng, Z.; Han, Z.L. Adjusted NIEL calculations for estimating proton-induced degradation of GaInP/GaAs/Ge space solar cells. Nucl. Instr. Methods Phys. Res. B 2011, 269, 1884-1886. [CrossRef]

8. Lu, M.; Wang, R.; Liu, Y.H.; Feng, Z.; Han, Z.L.; Hou, C.Y. Displacement damage dose approach to predict performance degradation of on-orbit GaInP/GaAs/Ge solar cells. Nucl. Instr. Methods Phys. Res. B 2013, 307, 362-365. [CrossRef]

9. Cress, C.D.; Hubbard, S.M.; Landi, B.J.; Raffaelle, R.P.; Wilt, D.M. Quantum dot solar cell tolerance to alpha-particle irradiation. Appl. Phys. Lett. 2007, 91, 183108. [CrossRef]

10. Messenger, S.R.; Burke, E.A.; Xapsos, M.A.; Summers, G.P.; Walters, R.J.; Jun, I.; Jordan, T. NIEL for Heavy Ions: An Analytical Approach. IEEE Trans. Nucl. Sci. 2003, 50, 1919-1923. [CrossRef]

11. Wang, R.; Liu, Y.H.; Sun, X.F. Effects of $0.28-2.80 \mathrm{MeV}$ proton irradiation on GaInP/GaAs/Ge triple-junction solar cells for space use. Nucl. Instr. Methods Phys. Res. B 2008, 266, 745-749. [CrossRef]

12. Browne, E. Nuclear data sheets for $\mathrm{A}=235,239$. Nucl. Data Sheets 2003, 98, 665-800. [CrossRef]

13. SRIM-The Stopping and Range of Ions in Matter. Available online: http://www.srim.org (accessed on 20 May 2018).

14. Dharmarasu, N.; Yamaguchi, M.; Khan, A.; Yamada, T.; Tanabe, T.; Takagishi, S.; Takamoto, T.; Ohshima, T.; Itoh, H.; Imaizumi, M.; et al. High-radiation-resistant InGaP, InGaAsP, and InGaAs solar cells for multijuction solar cells. Appl. Phys. Lett. 2001, 79, 2399-2401. [CrossRef] 
15. Hu, J.M.; Wu, Y.Y.; Xiao, J.D.; Yang, D.Z.; Zhang, Z.W. Degradation behaviors of electrical properties of GaInP/GaAs/Ge solar cells under $<200 \mathrm{keV}$ proton irradiation. Sol. Energy Mater. Sol. Cells 2008, 92, 1652-1656. [CrossRef]

16. Zazoui, M.; Bourgoin, J.C. Space degradation of multijunction solar cells: An electroluminescence study. Appl. Phys. Lett. 2002, 80, 4455-4457. [CrossRef]

17. Makham, S.; Zazoui1, M.; Sun, G.C.; Bourgoin, J.C. Non-empirical prediction of solar cell degradation in space. Semicond. Sci. Technol. 2005, 20, 699-704. [CrossRef]

18. Lu, M.; Xu, J.; Huang, J.W. Non-ionizing energy loss calculations for modeling electron-induced degradation of $\mathrm{Cu}(\mathrm{In}, \mathrm{Ga}) \mathrm{Se}_{2}$ thin-film solar cells. Chin. Phys. B 2016, 25, 098402. [CrossRef]

19. Messenger, S.R.; Burke, E.A.; Summers, G.P.; Xapsos, M.A.; Walters, R.J.; Jackson, E.M.; Weave, B.D. Nonionizing Energy Loss (NIEL) for Heavy Ions. IEEE Trans. Nucl. Sci. 1999, 46, 1595-1602. [CrossRef]

20. Goodman, S.A.; Auret, F.D.; Meyer, W.E. The effect of alpha-particle and proton irradiation on the electrical and defect properties of n-GaAs. Nucl. Instr. Methods Phys. Res. B 1994, 90, 349-353. [CrossRef]

(C) 2018 by the authors. Licensee MDPI, Basel, Switzerland. This article is an open access article distributed under the terms and conditions of the Creative Commons Attribution (CC BY) license (http:// creativecommons.org/licenses/by/4.0/). 